J. Management and Humanity Research

Vol. 3, 2020, 1-8

ISSN: 2582-7766 (online)

Published on 15 July 2020

www.researchmathsci.org

DOI: http://dx.doi.org/10.22457/jmhr.v03a01101

Journal of

Management and

Humanity Research

\title{
Credit versus Online Loans: A Case Study from China
}

\section{Zhaomin Shi}

\author{
School of Economics and Management \\ Chongqing University of Posts and Telecommunications \\ Chongqing 400065, China. Email: 644919005@qq.com \\ Address: No. 2 Chongwen Road, Nan'an District, Chongqing 400065, China
}

Received 1 May 2020; accepted 2 July 2020

Abstract. Under the background of Internet finance, diversified financing modes have broken the pattern of bank loans as the only way of financing and brought an unprecedented impact on traditional credit. This paper compares commercial bank credit and online loans, and introduces the overview, development status and problems of traditional commercial banks' credit card business and ant-payments as examples, and finally compares the advantages and disadvantages of both in terms of application requirements and security in mass consumption.

Keywords: Internet finance; credit; online loans

\section{Introduction}

In recent years, China's economy has grown at a rapid pace and commercial banks still dominate the country's financial system. With the development of Internet information technology, more and more P2P online lending platforms have emerged to shake the core position of commercial banks' credit business. With the emergence of new businesses, traditional commercial banks' businesses have been greatly impacted by the lack of innovation, which is detrimental to the development of commercial banks. With the development and maturity of Internet information technology, Internet finance has not only promoted the development of China's commercial banks, but also brought huge threats and challenges.

Bank is the center of the financial system. As one of the most important business of commercial banks, credit plays a decisive role in the stable development of banks. However, the derivatives of Internet finance have rapidly occupied a large market share in a short period of time, which has slowed down the growth of commercial banks' credit business. Therefore, the transformation and upgrading of commercial banks' credit business cannot be delayed. The rapid development of consumer credit has changed the traditional consumption structure while stimulating residents' consumption, and the growth of residents' consumption expenditure has boosted the growth of the national economy at the same time. The rapid development of Internet finance not only promotes the development of commercial banks, but also makes them face more challenges, so it is extremely important to avoid the harm and maintain the stable development of commercial banks. 


\section{Zhaomin Shi}

Relevant literature has discussed some of the above topics. Ruohan proposed that there is a competitive relationship between the credit business of commercial banks and online lending under the background of the Internet, but the development of Internet finance makes this competition even more intense [1]. Junyang was one of the first to put forward the contradictory relationship between commercial banks and small and mediumsized enterprises, because the information of both sides is difficult to correspond and correct [2]. Fan Gang verified in Financial Development and Enterprise Reform that the main reason for SMEs' difficulty in financing from commercial banks is information asymmetry [3]. Hu Shuang made a comparative study of relevant industry data in the development of consumer credit in China and developed countries and demonstrated that the development of consumer credit business could increase consumers' consumption in the current period based on the liquidity constraint theory. By selecting the corresponding proxy variables and conducting empirical tests, it is finally proved that the development of consumer credit is conducive to increasing the consumption of residents [4]. Chuyu confirmed that the rise of Internet finance has slowed down the growth of commercial banks' personal credit and squeezed the traditional personal finance business [5]. Hou and Hou proposed that commercial banks should take the initiative to combine their own business with Internet technology to deal with the challenges in the face of the strong blow of Internet finance [8]. Tess Ocean compares traditional commercial bank loans with online loans, and concludes that the latter has the advantages of larger customer groups, lower costs, more convenience, and better ADAPTS to social changes and progress [9].

This paper analyzes the impact of online loans on the credit business of commercial banks in the context of the Internet from multiple perspectives and aspects.

\section{Credit loans and online lending}

Unlike other forms of loans, credit is a form of loan that is initiated by the borrower and is guaranteed by his or her creditworthiness, and does not require any collateral or guarantee. Based on this form of loan, credit loans are widely respected among young people today, as most of them are "moonlighters" and have a high demand for consumption but no savings to support it, so credit loans have become their first choice for consumption. Since there is no collateral or guarantee, the risk of this form of loan is relatively high.

Credit loans exist in most commercial banks today. This form of loan has high requirements for debtors, and before loan approval, they will be evaluated based on their credit reports in the People's Bank of China's credit system. Since the People's Bank of China's credit system is not yet perfect, the lending bank will also conduct a comprehensive review and evaluation of the borrower's salary level, asset status, loan and repayment situation, etc. The evaluation results will directly determine the outcome of the loan application. In the new version of the personal credit report that went online this year, defaulting on water bills may also be a credit risk. The credit mentioned separately in this article mainly refers to commercial bank credit loans.

Online lending is a lending platform based on the Internet background, most of this form of loan does not require any guarantee or collateral, many P2P platform is to mislead people under the banner of 'same-day application, same-day lending'. Based on the development of Internet information technology and the spread of third-party 


\section{Credit versus Online Loans: A Case Study from China}

payment platforms, online lending platforms have gradually replaced traditional credit as the mainstay of the loan business, especially in daily consumption, most consumers' payment method is Alipay, and the Alipay platform's ant chanting has naturally become people's first choice for early consumption. Moreover, P2P platform also provides a new financing channel for small and medium-sized enterprises in China besides commercial bank loan financing. In terms of financial management, P2P platforms are even more flourishing.

\section{Credit analysis of commercial bank credit card business as an example 3.1. Basic Overview of Credit Cards}

Credit card is a credit certificate issued by commercial banks or credit card companies to credit-qualified consumers. The cardholder can make purchases at specific locations where the credit card can be used, and the amount spent must be within the individual's credit limit. The bank will settle the account with both the merchant and the cardholder at a fixed time each month, and no interest will be charged if the cardholder pays off the amount used before the repayment date. In the credit card just launched stage, the system is not quite perfect, mainly quasi-credit card, this credit card requires the user to deposit a certain amount of reserves, after using the reserves and then overdraft, but the current public use is mostly credit card, that is, the bank gives the cardholder a certain amount of credit, the cardholder can directly overdraft spending within the limit. Credit cards in this article refer to credit cards alone.

\subsection{Current status of credit card development}

According to the information collated from public data, the number of credit card issuance has been largely increasing since 2002, and as of 2017, the number of credit card issuance nationwide has reached 571 million. According to the research results, the number of credit card issuance is positively correlated with the degree of urban development, among which Beijing, as the capital of China and one of the most developed cities in the country, has 1.35 credit cards per capita, far exceeding the national average.

In terms of quantity, the development of commercial banks' credit card business is still relatively stable, but there are still a lot of problems in the actual use. Many commercial banks have been pursuing the number of issuance and ignoring the real usage of credit cards, and there are many 'zombie cards', which is not good for both banks and users. For users, the annual fees incurred by credit cards that have not been used are easy to ignore. Although the annual fees are small, they can easily affect the applicant's credit if they are not paid on time. For banks, the existence of zombie cards greatly increases the processing burden. The continuous issuance of credit cards is undoubtedly a new consumer stimulus for mass consumers.

From the credit card holder group distribution statistics of Consumer Finance Theory, the credit card holders are mainly concentrated in the post-80s and post-90s, but the proportion of mobile payment is much higher in the post-90s than in the post-80s, and there is a trend of increasing decrease or loss of credit card holding and consumption in this group. The largest number of credit card holders is in the post- $80 \mathrm{~s}$, because people in this age group are the first to be exposed to credit card business and have relatively strong consumption ability, so it is easier to accept credit cards. 


\section{Zhaomin Shi}

\subsection{Risks in credit card development}

Credit card cashing is the act of obtaining cash through illegal means on the basis of not paying interest, which is an illegal act expressly prohibited by our laws. The act of cashing out has been unstoppable since the first time it happened, bringing considerable risk while also causing loss of bank assets. The development of Internet information technology has also created opportunities for lawbreakers to obtain cardholders' basic information and spending authorization by sending links and providing free WI-FI, and then commit credit card skimming, an illegal act that has caused huge losses to both cardholders and banks [6].

According to the report released by the Central Bank, the number of credit cards in China is close to saturation, which, coupled with the competitive pressure from emerging industries, has slowed down the growth rate of China's credit card business. The basic system in China is not perfect, especially in the context of the Internet, and the problems and loopholes are exposed, which should be strictly regulated by both the state and the banking industry itself. The emergence of Internet finance has greatly reduced the use of credit cards, which means that the income of commercial banks in credit card business will also be reduced.

\section{Analysis of online loans using ant credit pay as an example 4.1. Basic overview of ant credit pay}

Ant Credit Pay is an online microfinance product launched by Alipay, which is mainly used by customers for daily consumption and online shopping. After registering with Alipay, users can open the account and get a certain amount of credit for their purchases. It was officially launched in April 2015 and is mainly used on Taobao and Tmall shopping platforms. Currently, there are many places and platforms where you can use Ant Credit Pay, ranging from small roadside fruit stalls to high-end shopping malls. The rapid development and popularity of third-party payments has also created innate conditions for such online microfinance products as Ant Credit Pay.

\subsection{Current development of ant credit pay}

As Figure 1 shows, the users of Ant Credit Pay are mainly concentrated in the post-80s and post-90s, especially the post-80s account for $49 \%$ of the total number of users, and the consumption level of the post-80s is generally higher than that of the post-90s, which drives the development of Ant Credit Pay even more. At present, you can use Ant Credit Pay on both online and offline platforms, without the limitation of time and space. The second largest user group, the post-90s, already has over 45 million users registered and set it as the preferred method of Alipay payment. Some major e-commerce platforms such as Tmall and Taobao have also been connected to Ant Credit Pay, and merchants on these platforms saw a 33\% increase in store transactions in the first month after accessing Ant Credit Pay, and continued to increase by $26 \%$ the following month. Not only Alibaba's e-commerce platform, but also some other consumer platforms have been connected to it, more than 40 in total.

In 2016, the first year of access, the total number of transactions on the platform reached 60.48 million, accounting for $8.5 \%$ of the total number of Alipay transactions. 
Credit versus Online Loans: A Case Study from China

However, in the first hour of 'Double 11', the number of chanting transactions reached $33.4 \%$, and the amount exceeded that of the whole day in 2015[7].

\section{Ant Credit Pay user distribution}

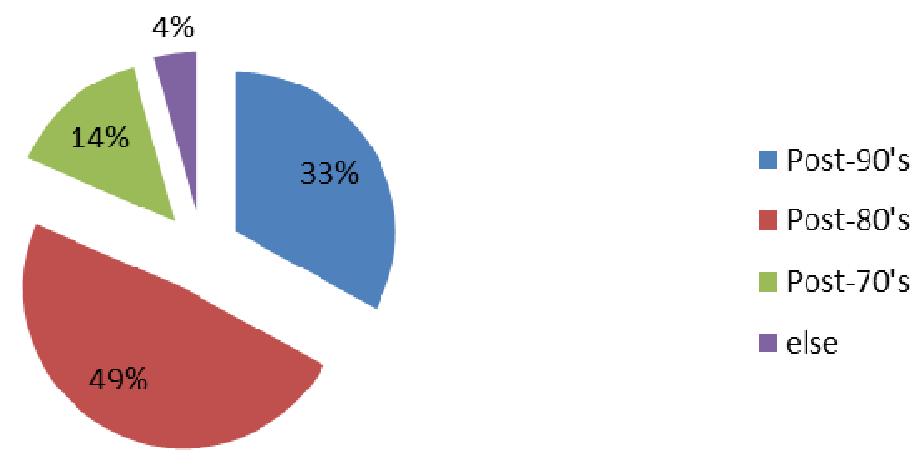

Figure 1: Distribution of Ant Credit Pay users

\subsection{Existing problems of Ant Credit Pay}

The launch of Ant Credit Pay has formed a strong stimulus to the public consumption, and the proportion of Ant Credit Pay in the annual growth of 'Double 11' transaction volume cannot be underestimated. The widespread use of Ant Credit Pay has been a great support to the e-commerce industry in China, but it is not beneficial to consumers themselves. The concept of spending money in advance is very attractive to college students who are not yet experienced in the world. Not only college students, but also adults, have been spending more or less impulsively because of 'Double 11', resulting in a huge waste of resources.

Ant Credit Pay is a derivative of Internet finance, based on the form of the Internet, the circulation is virtual money, although there is no direct risk compared to cash transactions, but the security of the Internet is still to be examined, the Internet is always a public platform, the protection of data still needs to be strengthened.

Most of the P2P platforms currently in operation are not registered for business, and as of 2017, only 85 network microfinance platforms are registered for business, such companies do not even protect themselves, not to mention the protection of customers.

\section{Comparison of the advantages and disadvantages of the two based on microfinance}

\subsection{Application requirements}

Commercial bank credit business is more stringent than online loans, and the application process is more complicated. The loan recipients are generally those who have the ability to repay the principal and interest on time and have no bad credit records. Although 'credit' is the main credential for credit business, before this business, commercial banks will evaluate the applicant's credit report, salary level, asset status and other aspects, and the evaluation will directly affect the outcome of the applicant's credit application. Although each online credit platform has different application conditions, online loans 


\section{Zhaomin Shi}

still highlights its advantages. According to the news released by Netflix, the application requirements for small loans mainly include salary, age and personal credit, but there are also platforms where you can borrow with just an ID card. Overall, applications for online loans are faster and more lenient than those for commercial bank credit.

\subsection{Security}

The regulatory mechanism of commercial banks is basically perfect. At the consumer level, the safety of commercial bank credit funds is higher than all online loans, and commercial banks have complete disclosure of various information and more transparent processes. As China's regulatory system for online lending is not perfect, resulting in the existence of many P2P platforms in the online lending industry that practice fraud in the name of fund raising. At present, the disclosure of various kinds of information in the online lending industry is incomplete and the authenticity is difficult to examine, and users cannot accurately identify potential risks. In general, commercial bank credit is more open and transparent than online lending and has higher security.

\section{Conclusion}

Commercial banks have high security of credit funds and transparent processes, while online loans in the context of the Internet have low application thresholds and fast lending speed. However, for consumption, especially after the emergence of Internet financial derivatives, the credit business of the original commercial banks is facing a great threat. The rapid development of third-party payment platforms for online microfinance products has also slowed down the growth of commercial banks' credit business. In short, the emergence of online lending products has formed a new challenge for commercial banks.

\section{REFERENCES}

1. R.Wu, The impact of online microfinance on traditional credit, China Finance, 7 (2015) 88-89.

2. J.Xi, Market orientation of bank commercialization - reshaping the relationship with SMEs, Finance and Economics Research, 3 (1998) 36-41+45.

3. G.Fan, Financial Development and Enterprise Reform, Economic Discipline Press, 2000.

4. S.Hu, The impact of consumer credit development on residents' consumption behavior, Dissertation of School of Foreign Affairs, 2018.

5. C.Zhou, The impact and response of Internet finance on the traditional business of commercial banks, China Economic and Trade Journal, 14 (2019) 55-56.

6. Y.Zhao, Exploring the current situation and development strategy of credit card business of Chinese banks, China International Finance and Economics (in English and Chinese), 4 (2018) 246-247.

7. X.Hu, Analysis of the development of Anthem and its prospect, China Township Enterprise Accounting, 10 (2017)17-18.

8. D.C.Chou and A.Y.Chou, A guide to the internet revolution in banking, Information Systems Management, (17)(2000) 250-260.

9. T.Ocean, Online Personal Loans: Access Easy Finance at Cheap Interest Rates, Intemetmonetary, (2013). 